\title{
Name Calling and Vulgarity as Threats to National Peace and Security: The Case of Language of Virtual Community
}

\author{
Godwin Oko Ushie \\ Department of English and Literary Studies, University of Calabar, Calabar, Nigeria \\ Juliet Ude Ifeakor \\ Department of English and Literary Studies, University of Calabar, Calabar, Nigeria
}

\begin{abstract}
This paper analyzes comments by readers of an online article in The Punch Newspaper entitled "CAN crisis deepens", the crises that threaten to rock the Christian Association of Nigeria, CAN. It aims to show how name calling and vulgarity as a trademark of language use in the virtual community can pose a threat to national peace and security. Some of the comments that trailed the article deviate from civility, break the conversational and politeness maxims, extend the frontiers of the discourse at hand and inundate it with name calling and vitriolic language. The method used in this paper consists of highlighting the comments and analyzing this discourse using Grice's Cooperative Principles and Politeness Principles of conversation. The paper concludes that public discourse among the netizens (members of virtual community) has the tendency of degenerating into expletives, discourtesies and disparagement because the public space is a faceless one; hence the comments which have deviated from the norms of civilized discourse pose a threat to religious peace and harmony among Christians in Nigeria and by extension to national peace and security.
\end{abstract}

Index Terms — name calling and vulgar language, virtual community, public discourse, conversational maxims, peace and security

\section{INTRODUCTION}

The article to which responses by netizen readers form the basis of this paper is about the recent crisis faced by the Christian Association of Nigeria (CAN) in relation to administrative issues in the association. The article contains a verbal response in an interview granted by the Public Relations Officer of CAN, Mr. Samuel Oibe, on the threat by the Catholic group to pull out its membership from the association. It was published in a daily online Nigerian newspaper, The Punch, on January 24, 2013 and it was entitled "CAN crisis deepens" and written by Friday Olokor. It is a short article, written for a well- informed virtual community to read and possibly comment on. It is evident that the reporter had been aware of the crises that CAN had been going through previously before this new development. For he starts the article with the statement, "The crisis rocking the Christian Association of Nigeria worsened on Wednesday as the association told the Catholic Church to go ahead with its decision to pull out of the association." The reporter gives the readers the comment made by the Catholic arm of the group through The Administrator of the Catholic Diocese of Abeokuta, Monsignor Christopher Ajala, alleging that "CAN had become an arm of government". The reporter reports that CAN attributes the Catholic's action to her loss of the Presidency of CAN to Pastor Ayo Oritsejafor, who doubles as the Pentecostal Fellowship of Nigeria's President presently.

The medium of communication affects discourse in the sense that it determines how liberal one can be when using different types of medium. Johnstone (2002) believes that the fact that the internet is more interactive is as a result of how the technology facilitates interactivity and there are beliefs of how the internet should be used. The virtual community users often cross the line of freedom of speech to libelous attacks on other users in their language use. Some of the comments presented here are cited as examples of such use of language.

The main purpose of this article like most online articles is to enlighten people about the problems in CAN and elicit comments from the public on their opinions on the issue at hand. Our interest in this article is aroused by the fact that name calling and vulgarity has become a major problem in the virtual communication media as evidenced in some comments on this article. Our thesis is that these vituperative comments can pose a threat to national peace and security by the nature of the language used by the commentators for words are a powerful weapon that can generate bad blood and incense the characters involved. Benjamin Disraeli, a $19^{\text {th }}$ century Prime Minister quoted in Harris (1976) asserts that "What words mean few can say, but with words we govern men" (p.53). Bad words can rule a reader's head, incense him and instigate a bad reaction. The multi-linguistic, multi-cultural and multi-religious nature of Nigeria calls for caution in the use of language in discussion bordering on national or religious issues especially in the virtual world where many people can read the comments as they come into a webpage. Nigeria has been under siege from a terrorist Muslim sect called Boko Haram that claims it is fighting Government but attacks Christian Churches and areas of high 
Christian concentration, banks and even burns schools in addition to Police Barracks. This has posed very serious security challenges to lives, property, churches and government since 2009. From the report in the article it is evident that the argument is between the Pentecostals and the Catholics and the mode of the utterances in the report has opened a can of name calling and vulgarity from the commentators. We have analyzed some of the comments to show the threat they pose to our national peace and security after summarizing the main topic of the article.

\section{Public Discourse in Nigerian Virtual Community}

Tollefsen (2009) defines public discourse as

a space in which the sort of public conversation necessary for a reflective opinion on public matters can develop. This common space was made possible in the eighteenth century by the developing print media, in the form of books, pamphlets and newspapers. At the heart of this common space, in turn, was a form of impersonal communication of ideas and arguments. But such a public space is at risk in an era of instantaneous communication and reaction, and competition to be heard above the din. Public Discourse has, as I understand it, been an attempt in part to recreate part of that public space, to recreate the context in which the impersonal communication of ideas and arguments can be carried out. It is not, of course, the entirety of that space, nor could it ever be: the essays of Public Discourse, while manifesting various internal disagreements amongst its contributors, nevertheless share to a generally high degree a common set of values, presuppositions, and standpoints.

Virtual community is the latest range in personal interaction and public discourse. It is an attempt to alleviate some of the alienation caused by modern society. People realize that there is some value in banding together through personal interactions: a way of people meeting other people and airing their views on topic of mutual interests. The nature of the discourse might have a negative or positive effect on the society. If it addresses adequately the topic at hand with the intent of finding solution to the problem or issue at hand through positive suggestions, it becomes beneficial to the community but if the contributions are not relevant to the discourse and turns into an attack with name calling and vulgarity as its weapons of warfare, then it is detrimental to the virtual community and even to the nation as a whole.

Ligaga (2012) asserts that the virtual space provides a forum for "a vast majority of people to articulate their opinions and desires, perform their identities, present the unsaid, circulate informal information, and to generally negotiate the meanings of political and cultural issues in their lives (p.2). In a recent interview with Thisday style magazine, the Finance Minister, Ngozi Okonjo Iweala, encourages the electronic media users to use it for good "to pass information that is true and needed for people to educate themselves, but [not to] use it to peddle false stories that may be damaging to people" (Sunday March 10 2013).

Kiesler \& Siegel, \& MacGuire (1984) found out that computer based medium of interpersonal relations are more difficult to work with because the group members often treat one another more rudely than the face to face medium of interaction and they were more likely to swear, insult other group members, make hostile comments, and engage in name-calling. This is a constant feature of the virtual community and it has adverse effects on the community.

Comments and reactions to news reports are of great interest to the public and topics relating to religion and politics are sensitive issues that a lot of people will like to contribute to. One of such topics is the issue of the crises in CAN and it is interesting to see the thread of comments that has been generated as a result. The antecedents in the crises and comments made by Oibe in which he said, "There are some certain elements in the leadership of CAN led by Cardinal John Onaiyekan because he lost CAN Presidency to Oritsejafor who has a lot of achievements" and "They have been agitating that the Presidency of CAN must come from the South. They are an appendage of PDP and PDP themselves. They are known for double standards. A man of God should not be double speaking", sparked a line of comments and responses, some of which were not even relevant to the threat of pulling out of CAN by Catholics but to the contextual issues associated with the corruption, decadence and flamboyance of either of the Catholic or Pentecostal denominations. The first comment (see Appendix below) sets off the firestorm of name calling and vulgar language that characterizes many of the other comments trailing the article.

These comments raise really important questions about free speech in the virtual community, and the way public discourse is engaged in as it relates to the larger communities. These comments are symptomatic of a larger problem, and this is the persistent presence of such name calling and vulgarity in language use of many Nigerians. Even in casual conversation, even when used in discourse with friends or relations we not only allow, but encourage the use of such language without knowing the consequences of such language use. In the same way that the use of derogatory terms based on differences is dangerous to the society as it can incite unrest and even war. The use of this type of vulgar language as seen in the appendix below is harmful to any and all efforts for national peace and security.

These commentators are well within their rights to freedom of speech just as much as anyone else. But having the right to say a word does not invite or encourage one to use that word. Name calling and vulgar language are part of offensive and inflammatory language at the expense of an entire community. This kind of language could incite a denominational or religious war in the country. The first comment, 1.0, starts with name calling, and comment 2.0 reacts violently to the first comment in a vulgar language. Name calling often does not open the door for dialogue in issues like this. Rather, such language that is offensive often slams the door for dialogue and logical reasoning when such divisive issues come to light on a national stage. If one is interested in having a reasoned, engaging and honest debate, one should probably do what one can to keep the other person engaged, reasonably and politely. Calling a 
person "an idiot" as in comment 6.0, for example, is almost certain to be deleterious to the conversation with many people, whether they are right to take offence or not. Therefore, if the motive is to have a reasoned, engaging and honest debate it is in the best interest not to make such predictably insulting assessments of either people or their ideas.

It must however be admitted that corruption in Nigeria, especially in government circles, still remains a cause for justified outrage, more so when it is being linked to religion. Corruption is a very serious problem and the solutions more fundamental than we most times would like to think it is. It is only through true discourse that public anger will be properly channelled towards finding positive solutions to this type of crises in CAN. That public anger, unfortunately, has been dissipated by people like the spokespersons of the two religious denominations involved in this crisis, in name calling and blaming the persons at the helm of affairs. On virtual social media where the limit on the number of interlocutors seems to be equivalent to a limit on the depth of reflection, public discourse has descended into the gutter barefacedly. The adverse effect of this is that after all the heated offensive language used no one proposes solutions as no one properly gets to understand the problem as the right questions are not asked resulting in a stagnant discourse with no way forward.

\section{Theoretical Framework: CoOperative AND Politeness PrinCIPLES IN Discourse}

It seems important, in the light of the flavour of this public discourse at hand in Nigeria to call to mind some qualities of mature and civilized public discourse which is also related to Grice's conversational maxims and Leech's Politeness maxims. H. P. Grice (1975), having studied conversational behaviour of interactants, discovered a pattern of cooperation between and among them. The pattern he christened "Cooperative Principle (CP)". The CP states that, "Make your conversation contribution such as is required, at the stage at which it occurs, by the accepted purpose or direction of the talk exchange in which you are engaged" (p. 45). From the CP itself he derived four conversational maxims that not only help in analysis of discourse, but also in explicating implicated meaning, because speakers tend to imply more covertly than what is overtly stated. And when a speaker breaks a maxim, he creates room for implicature.

Leech's (1983) Politeness Principle (PP) is a necessary compliment to Grice's cooperative principle. He identifies politeness as concerning a "relationship between two participants whom we may call self and other" (p.131) in which a speaker the (self) employs all forms of tact and diplomacy so as not to pose a Face Threatening Act to the other who may be an addressee or even a third person. The function is "to maintain social equilibrium and the friendly relations which enable us to assume that our interlocutors are being cooperative in the first place" (p.80).

Koester (2006) notes that "Brown and Levinson (1978/1987) distinguish between positive and negative politeness. Both types of politeness involve maintaining--or redressing threats to--positive and negative face, where positive face is defined as the addressee's 'perennial desire that his wants . . . should be thought of as desirable' (p. 101), and negative face as the addressee's 'want to have his freedom of action unhindered and his attention unimpeded' (p. 129)." Although Leech derives from the politeness principles six maims, only the following maxims will be used in the analysis of these deleterious comments: Tact Maxim, Approbation Maxim and Modesty Maxim. He categorizes "the maxims of PP which tend to go in pairs as follows:"

1. Tact Maxim in impositives and commisives

a. Minimize cost to the other.

b. Maximize benefit to the other.

2. Approbation Maxim (in expressives and assertives)

a. Minimize dispraise of others.

b. Maximize dispraise of self.

3. Modesty praise Maxim (in expressives and assertives)

a. Minimize praise of self.

b. Maximize praise of others (p.132).

Grice's first Maxim is that of quality and it states that you "make your contribution as informative as is required (for the current purposes of the exchange)" and secondly, "do not make your contribution more informative than is required." The minimal requirement is that the discourse should be informative. We can understand this minimal requirement using inference. The main idea is that an utterance must contain something new to be informative. And for it to contain something new logically, the content of the utterance must not be implied by the preceding discourse anyway. We know that if it is implied, the implication with the preceding discourse as antecedent and the (not so) new utterance as a consequence will be valid.

So, to find out whether comments 1.0 and 2.0 are informative, for example, we check whether the 1.0 is informative based on the article it is meant to react to.

"PRIVATE JETS PARADE. AM GLAD FED GOVT HAVE BANNED THEM.CATHOLIC CHURCH ISNT THE PROBLEM. ITS [sic] A FACT THAT THE ASSOCIATION IS FAST LOSING FOCUS AND MORAL TEACHINGS OF CHRISTIANITY"

This statement is valid because it gives new information that is not contained in the article about the "private jets", "loss of focus" and "moral teachings of Christianity" is a statement that is also verifiable so we can take it to be informative so it does not violate the principle of quantity. But it flouts the maxim of Relation in that the issue of ownership of private jets is extraneous. It is not part of the reason that the Catholic Church is adducing for pulling out of 
CAN. Rather its inclusion is part of the mischief making and generation of bad blood. It also flouts Leech's Tact Maxim, which states that: "Minimize cost to the other". This information about private jet ownership is in bad faith and is intended to cost the CAN President who had just acquired a private jet a "praise"; in fact it is a ridicule, especially with the allusion to the CAN's "loss of focus and moral teaching... [and a hint on the President becoming a] PASTORPRENEUR". The coinage "PASTORPRENEUR" is a blend of two words, "pastor" and "entrepreneur", meaning one who makes merchandise of his pastoral vocation, which is part of loss of focus. Nigerians are noted for casting aspersions on their leaders; hence Oritsejafor is suffering same here. Grice's point is not that utterances violating any of the conversational maxims are ill-formed in the sense of ungrammatical strings. Rather, a speaker may violate a maxim on purpose, allowing the hearer to infer "backwards" to the speaker's intention. This is the case for the comment 2.0 which is filled with vulgarity. There is no new information given in relation to the topic of the article both endophorically and exophorically.

The second Maxim which is that of Quality, is often called Super maxim. It is also important to this discourse. It states that we should "try to make our contribution one that is true". It is paraphrased in the statements below: (a) "Do not say what you believe to be false. (b.) Do not say that for which you lack adequate evidence." This presupposes that Speakers should aim to put forth the truth. The realization that an opponent's view, no matter how mistaken, has a little bit of truth in it, is an important quality of a reasoned discourse. Thomas Aquinas, the great philosopher and theologian, when refuting erroneous ideas, always states the 'objections' first. He would always explain the other point of view even better than its advocates could before he goes ahead to systematically refute them. It is usual in public debate these days for both sides to totally disregard any opposing viewpoint, sometimes fill their views with name calling, invectives and vulgarity that have adverse effect on the society, examples of which are the comments in 10.0, 11.0 and 12.0 below:

10.0 KkJanuary 24, 2013 at 11:45 am

$\mathrm{U}$ will remain a fool forever

11.0 AweluJanuary 24,2013 at 2:24 pm

CAN IS CAN FULL OF WORMS, THAT WILL BE REJECTED BY TIN CAN ISLAND. WE NEED SOMEBODY WITH A CAN OPENER TO LIFT THE LID OF THE CAN AND WE SEE WHAT TYPE OF WORMS AND CANKER WORMS ARE IN THE CAN. THE CANSOCK MEN APPOINTED TO LOOK AFTER CAN HAVE NOW STEEL THEMSELVES AND FORM A CANNABIES PARTY TO CANNIBALISE THE CANGREGATIONS. WE NEED MEN WITH TEARGAS CANNISTER TO CANSTRATE THESE MEN WHO ARE CANAL MINDED. THE PENTECANSTERS ARE CANNING THE CRUMBS FROM THE LOOTERS

12.0 edJanuary 24,2013 at 3:06 pm

Na your papa and your whole families and Your generation, Generation that will pull out or Resign, yeye man, shutup if you no knwo wetin you go talk.

These are not qualitative assertions from Grice's point of view and they can be referred to as an ad Hominem. For instance KK, Respondent 10.0 responding to Oare Ugbekpe's (Respondent 9.0's) call for proof to an assertion, resorts to calling him "a fool forever". An ad Hominem attack is not an argument; rather it is an attack on the personality of a participant in a discussion by the use of abusive language. It is important to note that the mark of a civilized discourse is that emphasis is placed on the topic of discourse brought forward and not on the person who makes them. Leech's Maxim of Approbation states, "Minimize dispraise of others." But here, we see KK Maximize dispraise of Ugbekpe, calling him a perpetual fool. And Awelu (Respondent 11) joining the fray, goes haywire in creative lexical coinage, and rolls out a derivational paradigm of CAN: 'CAN...of worms', can opener, cankerworm, 'cansock men, ' cannabies party to cannibalise the cangregations', teargas cannister to canstrate', 'canal minded,' 'the pentecansters'and 'canning'. It is very likely that this contributor is a non-pentecostal, ie if he is a Christian at all. To go to the extent of casting this kind of aspersions on the umbrella Christian association that aggregates the views of Christians in Nigeria, liaises with government and Muslims and cooperates in interreligious fora in a religiously volatile ambience like Nigeria is dangerous, counterproductive and capable of inciting different Christian organizations among themselves or even against Muslims if there is any hint that Awelu is a Muslim. What is commonly found in the Nigerian virtual discourse is a tendency to easily resort to attacks on the person whose view differs from theirs by resorting to name calling and vulgarity. There are comments like "PAY AS U GO PASTORPRENUERS" or "ignorant and hypocrite of the highest order". Rather than focus on the issue of the article, people tend to descend to abusive language and inveigh the person's personality. Most times contributors get caught up in name calling, expletives, disparagement and vulgarity that they do not even remember what the main issue of the argument is in the first place. Personal grouses should be kept out of the public square and issues have to be dealt with squarely.

Grice's Maxim of Relation states that you should be relevant. Grice (1975, p. 47) defines it as follows: "I expect a partner's contribution to be appropriate to immediate needs at each stage of the transaction". The flouting of this principle often happens when the comment is irrelevant to the topic, there is an entire change of topic or failure to address the goal of the question asked some of which have been observed in the comments above. Leech (1983, p. 94) provides the following definition of the notion of relevance: "An utterance $U$ is relevant to a speech situation if $U$ can be interpreted as contributing to the conversational goal(s) of speaker or hearer". Leech states that the speaker strives for a certain goal by stating his question and that the hearer adopts this goal when giving an answer. For example, all the comments listed above; do not have any relevance to the issue of the Catholic Church pulling out of CAN. The 
comments do not abide by the principle of relevance, since a direct and appropriate answer to the question is not given. See for example, comments 4.0, 5.0, 6.0 and 7.0.

Again, some of these comments flout this Maxim by making statements that are not relevant to the article's message. Take comments 2.0 and 3.0 for example, the vulgar attack on the comment made by 1.0 is absolutely, unnecessarily making the comments a charade of personal insults on the personality of the first commentator and having little or no comments on the actual topic of discussion. For this reason it floats the Maxim of Relation.

The cooperative Maxim of manner makes the following requirements: 'Be perspicuous'. It proposes that the participants should:

(a) Avoid obscurity of expression. (b)Avoid ambiguity. (c) Be brief (avoid unnecessary prolixity). (d) Be orderly.

This cooperative Maxim relates not to what is said but how it is said. Leech $(1983$, p.100) distinguishes two kinds of clarity: "One kind consists in making unambiguous use of syntax and phonology of the language in order to construct a clear text. Another type consists in framing a clear message, i.e. a message which is perspicuous or intelligible in the sense of conveying the intended illocutionary goal to the addressee." The illocutionary goal in these comments is its

efficient cause, that is, the force which the speaker intends to apply to his or her environment.

In this case the cause that can come out of name calling and vulgar language in the virtual community is chaos and national insecurity since the country is a multi-religious nation. It can rightfully be said that the perlocutionary goal will be nothing different from the act itself, changing the environment into a chaotic and insecure state. Respondents 7 and 11 comments are not only disorderly, they are also prolix."I knew him when he was a young boy in Sapele, very rascal, and he did smoke indian hemp then (what we in Warri and Sapele) call goof." Why don't you and all the members of your family including your linage from generation to generation. (emphasis ours). By reeling out series of unprintable and unverifiable things about the person Ayo Oritsejafor instead of CAN, the contributor of Comment 7 has flouted the Maxims of manner, Approbation and Modesty. Of Modesty because presenting in that light is tantamount to saying he is more righteous that the other. Hence, he has maximized dispraise of the other and maximized praise of self by implication.

\section{CONCLUSION}

It seems that intelligent virtual discourse in Nigeria, especially when it comes to religious matters, has been replaced with name calling, vulgarity, insults, childish hyperbole and a game of vicious slander that accomplishes absolutely nothing except to cause chaos that threatens the nation's security. Examples of name calling and vulgarity in the virtual community have been examined above in an attempt to show how offensive people's choice of language use can be and the adverse effects it may have on the society.

One of the distinctive marks of the ancient Greek civilization according to a blog entitled, 'What happens to today's discourse', was its openness to reasoned discourse in the continuous search for truth symbolized by the Aeropause: a place where ideas no matter how novel or esoteric could be entertained, analysed and critiqued; whether it be from Socrates or St. Paul. This openness to discourse remains a mark of societies who pride themselves as enlightened. The virtual community should be a community of enlightened people who should be ready to contribute positively to the unity and peace of the country.

Judging from the manner in which the aggrieved parties in CAN have presented their crises to the public by unwarranted accusations and rivalry between the two predominant factions of CAN, they have opened the door for the public to follow in airing their views and comments which mostly have deviated from the real issue to name calling and vulgarity. These comments are detrimental to national peace and security and all virtual community members should be aware of this and avoid such language use that extends to name calling and vulgarity the electronic media. Reclaiming the meaning of true discourse in the Nigerian public square is a matter of urgency. The issues will not go away. Answers must be given and we cannot afford to waste our energies on irrelevant personal feuds that can be a threat to national peace and security. Being a part of an enlightened minority who shape public debate demands a sense responsibility and maturity. The anonymity of contributors which the public space discourse in the cyberspace allows, without any fear of censorship or threat of litigation, is responsible for the deleterious and vituperative contributions that throw caution, civility and politeness to the winds. The uncouth language in the comments is indicative of street and drinking joints controversies that often degenerate into brawls. The commentator's language shows a diametric oppositeness to all the Maxims of politeness principles.

Administrators of online news sites can do well to edit such outrageous and uncivil comments and spare the reading public the bad blood generated by the comments.

\section{APPENDIX}

1.0 ozaluokuJanuary 24, 2013 at 1:17 am

WHICH VALUES IF I MAY ASK.?...PRIVATE JETS PARADE. AM GLAD FED GOVT HAVE BANNED THEM..CATHOLIC CHURCH ISNT THE PROBLEM. ITS A FACT THAT THE ASSOCIATION IS FAST LOSING FOCUS AND MORAL TEACHINGS OF CHRISTIANITY...LETS TRY KUMUYI RATHER THAN PAY AS U GO PASTORPRENUERS 
2.0 IsraelJanuary 24,2013 at $2: 32 \mathrm{pm}$

Why don't you and all the members of your family including your linage from generation to generation EMBRACE POVERTY IN ALL it's ramifications by requesting God to place it heavily on you if you hate Christendom prospering legitimately, so that your generations yet unborn can remain servant to Almajiris? This is because you hate prosperity; ignorant and hypocrite of the highest order.

Other related comments of such vulgarity and abuse are:

3.0 Desire January 24, 2013 at 4:03 am

There is no dirty clothes anywhere. Most of these CAN people are CAN OF WORMS. They are mostly CULTS and the leadership has slaughtered its mandate in the market square of Politics.

4.0 AbidemiJanuary 24, 2013 at 5:36 am

You cannot put thieves to safe-guard your properties and still expect all your properties to be intact. Am not a Catholic and neither do i need Catholic to tell me that CAN president is a political thief. One day his own karma will fall badly on him and his generations to come.

5.0 JohnJanuary 24, 2013 at 7:31 am

Catholics are bunch of hypocrites, they should be ashame of themselves, child molesters bishops all over the world. I dey laugh oohhhhhj.

6.0 iiwuabaJanuary 24,2013 at 7:57 am

you are an idiot for saying that,i know you must be a member of all these mushroom fraudstars called churches

7.0 Onetosan AmorighoyeJanuary 24, 2013 at 8:35 am

Ayo Oritsejafor is a dubious fellow. I knew him when he was a young boy in Sapele, very rascal, and he did smoke indian hemp then (what we in Warri and Sapele) call goof. This is real. I knew Ayo when his late wife was still alive. Then, he was dating one of the lady in the choir. That is the same lady Ayo Oritsejafor is married to now, after his wife's death. I knew Ayo when he called influential members of his congregation for a spiritual journey to the West, and there was a mysterious ghastly motor accident, which claimed the lives of some of the congragation in that journey - including Ziregbe the owner of TOMAB. I have seen Ayo Oritsejafor one night entering that Ogboni building at Ginuwa Road in Warri. At that time of 9.30pm, what was a so called man of God going to do in that place? Made me wonder if Ayo had joined Emmanuel Uduaghan and most of the PDP crooks into the Ogboni Confraternity. Nigerians, all that glitters is not gold! Most of the people calling themselves Pastors in Nigeria today are nothing but crooks and fraud, including Ayo Oritsejafor. Almighty God will digrace them all, in the name of Jesus Christ.

8.0 Elvis TabohJanuary 24, 2013 at 8:50 am

Mr. Sunny Oibe or whatever your name is, you are very stupid, your so call apostolic churches are fraudsters, Ayo Oritsejafor has become a politics, he is no more CAN president, Catholic should go ahead and pull out, today Ayo Oritsejafor will be in Aso rock tomorrow he will come back, what is her doing there, is he a politician of a pastor, 419 pastors.

9.0 Oare Ugbekpe January 24, 2013 at 11:15 am

You have not provided proof to show he is shady. People like you are the perverts in society who cry wolf where there is none!

10.0 KkJanuary 24, 2013 at $11: 45$ am: $\mathrm{U}$ will remain a fool forever

11.0 AweluJanuary 24,2013 at 2:24 pm

CAN IS CAN FULL OF WORMS, THAT WILL BE REJECTED BY TIN CAN ISLAND. WE NEED SOMEBODY WITH A CAN OPENER TO LIFT THE LID OF THE CAN AND WE SEE WHAT TYPE OF WORMS AND CANKER WORMS ARE IN THE CAN. THE CANSOCK MEN APPOINTED TO LOOK AFTER CAN HAVE NOW STEEL THEMSELVES AND FORM A CANNABIES PARTY TO CANNIBALISE THE CANGREGATIONS. WE NEED MEN WITH TEARGAS CANNISTER TO CANSTRATE THESE MEN WHO ARE CANAL MINDED. THE PENTECANSTERS ARE CANNING THE CRUMBS FROM THE LOOTERS

12.0 edJanuary 24,2013 at 3:06 pm

Na your papa and your whole families and Your generation, Generation that will pull out or Resign, yeye man, shutup if you no knwo wetin you go talk.

13.0 genoscoJanuary 24,2013 at $4: 49 \mathrm{pm}$

I dont even know when these Penti of people leave their PENTECOSTAL association of Nigeria to join CAN. This people work against a known man of God TB JOSHUA. I Think this Penti people are becoming a very big problem to this nation. In their Churches no standard, no formular, behave as you like provided you pay your tithe, sow seed and donate money, you can wear pant, brassiere or come to church naked, no wahala. Now they are in the leadership of can wahala again. I adviced both the ANGLICAN CHURCH and METHODIST to leave CAN for this money mongers.

\section{REFERENCES}

[1] Grice, H.P. (1975). Logic and Conversation. In: P. cole and J.L Morgan (Eds), Syntax and Semantics, Vol. 3. New York: Academic Press, pp.41-58.

[2] Harris, P. (1976). Foundations of political science. London: Hutchinson.

[3] Johnstone, B. (2002). Discourse analysis: introducing linguistics. Malden, MA: Blackwell Publishers. 
[4] Kiesler, S., Siegel, J. \& MacGuire, T. (1984). Social psychological aspects of computer-mediated communication. American Psychologist, 39, 1123-34.

[5] Koester, A. (2006). Investigating workplace discourse. Abingdon: Oxon, Routledge.

[6] Ligaga, D. (2012)."Virtual expressions": Alternative online spaces and the staging of Kenyan popular cultures. Research in African Literatures.43/4. Measuring time: Karin Barber and the study of everyday Africa.

[7] Leech, G. (1983). Principles of Pragmatics. Essex, London: Longman.

[8] Olokor, F. (2013, January 24). CAN crisis deepens. The Punch. Retrieved from http://www.punchng.com/news/can-crisisdeepens/1.06A.M.

[9] Osime, R. (2013, Sunday March, 10 pp. 52-56). Ngozi Okonjo -Iweala: Simplicity \& Poise. Thisday Style, Vol. 17 , No. 6529.

[10] The Failed Rift (Blog) (February 8, 2013). What happened to today's discourse Retrieved from http://failedrift.wordpress.com/tag/culture/.5.05 A.M.

[11] Tollefsen, C. O. (April 8, 2013). What is public discourse? Retrieved from http://www.thepublicdiscourse.com/2009/10/945/ 4.14 A.M.

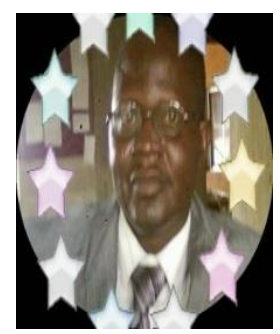

Godwin Oko Ushie was born on April 21, 1966 in NyanyaUlim, Bekwarra, Cross River State. He holds a Bachelor of Arts (Education) English, a Master of Arts (morphology) and a Doctor of Philosophy (stylistics), obtained from the University of Calabar, Calabar, Nigeria. He has been teaching English courses at both undergraduate and graduate levels such as Discourse Analysis, Textlinguistics, Stylistics, Morphology, etc at the University of Calabar for sixteen years now.

He is currently on a Sabbatical Leave at the Federal University, Lafia, Nasarawa State. He has at least thirteen (13) research articles in reputable local and international journals such as "Dialectical relexicalization in Festus Iyayi's literary idiolect: Componential analysis approach." LWATI: A Journal of Contemporary Research, June 2011 pp.92-100; Descriptive focus as a semiotic marker in Festus Iyayi’s Violence. Studies in Literature and Language Vol. 5, No. 3, 2012, pp. 36-39."The peculiar English pronoun "I" in Research on Humanities and Social Sciences.Vol.3, No.6, 2013 pp.71-75; "The nexus between social concerns and style: A study of selected poems in UnimnaAngrey'sDrought (Ubuang). "in World Journal of English Language Vol. 3, No. 2; 2013, pp.45-51, etc.

Dr. Ushie's research interests include Stylistics, Semiotics and Applied English Linguistics. He is a member of the Reading Association of Nigeria (RAN) and Association of Nigerian Authors (ANA).

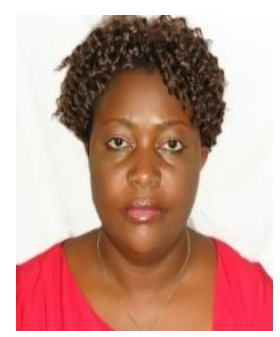

Juliet Ude Ifeakor is from Ogwashi-Ukwu, Delta State in Nigeria. She holds a Bachelor's Degree in English and Literature from the University of Benin, Benin City Edo State, Nigeria (2000) and a Master's Degree in English and Literary Studies, University of Port-Harcourt, Rivers State, Nigeria (2010). Her major field of study is English language. She's enrolled for a Ph.D programme in English at the University of Calabar, Calabar, Nigeria.

She currently works as an Administrative Officer in Johnchris Communications Limited in Port-Harcourt, Rivers State. She has research interest in Discourse Analysis. 